Serhii Indyk, Volodymyr Lysechko

Ukrainian State University of Railway Transport, Kharkiv, Ukraine

\title{
THE STUDY OF ENSEMBLE PROPERTIES OF COMPLEX SIGNALS OBTAINED BY TIME INTERVAL PERMUTATION
}

\begin{abstract}
The results of statistical analysis of cross-correlation properties of complex signals' ensembles, were obtained due to time interval permutations are presented in this paper. The essence of the method is to apply the division of short videopulse sequences at the level of intervals with low interaction in the time domain with different numbers of pulses. By applying the cross-correlation analysis, the maximum emission values of the side lobes of the crosscorrelation functions are calculated and its total average value is determined. Based on the obtained values, a series is formed in which the first position is occupied by a time interval in which the value of the maximum emissions of the side lobes of the cross-correlation function has an average value. The determination of the following time intervals is based on the analysis of the rating series and the arrangement of values is carried out in accordance with the selected total average value. Thus, a new average range of the maximum emission values of the side lobes of the crosscorrelation function is formed. The average range increases the number of ensembles with satisfactory cross-correlation properties for use in radio communication systems with code division multiplexing, and minimal interaction between signals in the time domain reduces multiple access interference.
\end{abstract}

Keywords : multiple access interference; videopulse; signal base; signal spectrum width; signal duration; crest factor; duty cycle; impulse duration; cross-correlation function.

\section{Introduction}

Problem statement. In multiple access systems with code division duplexing the subscriber signals are overlapped randomly in time and transmitted in a common frequency band, resulting in multiple access interference (intrasystem interference). Such interferences are characteristic, for example, of cognitive radio systems and are embedded in the very principles of their construction.

Current trends in the development of wireless systems require a further increase in the number of subscribers and the quality of service in wireless multiple access networks.

Assessment of the cross-correlation function (CCF) allows determining the cross-correlation properties of complex signal ensembles obtained by permutation of time intervals, due to which a significant increase in the number of ensembles of such signals and a decrease in the maximum emissions of side lobes, due to which the level of multiple access interference remains relatively low.

The received signals should be used in radio communication systems with code division multiplexing, and increasing the number of ensembles allows increasing the number of subscribers in them.

Therefore, the study of ensemble properties of complex signals obtained by permutations of time intervals on the basis of the rating series is an urgent task.

Literature analysis. Assessments of the $\mathrm{CCF}$ for the communication systems with code division multiplexing are widely considered in the literature for phase-manipulated, amplitude-manipulated, discrete and other signals based on linear and nonlinear sequences [1-5], but the correlation properties of complex signal ensembles obtained by permutation of time intervals based on rating series with the arranged values in accordance with the selected common average value have not been performed and thus require further study.

\section{The basic material}

Signals in code division multiple access systems should provide the lowest possible level of multiple access interference, which is mainly determined by the allowable level of maximum peaks of CCF [6].

$$
R \max =\frac{\alpha}{\sqrt{B}}
$$

where $\alpha$ - crest factor of CCF, in the general case depend on the signal base $B$.

$$
B=\Delta F \cdot T,
$$

where $\Delta F$ - the signal spectrum width, $T$ - the signal duration.

The larger the value of the crest factor, the better the correlation properties of the signal.

For the synthesis of complex signal ensembles, a sample of short video pulses sequences was chosen, which are divided into four equal intervals with the equal pulse durations

$$
\tau_{i}=\tau_{j}
$$

the periods of pulse duration are selected approximately equal:

$$
T_{i} \approx T_{j},
$$

with signal duty cycle

$$
Q_{i} \approx Q_{j} \gg>1,
$$

in so doing, the number of impulses entering each segment may differ

$$
n_{i} \neq n_{j} .
$$

The examples of the output sequence and the first two intervals after division are presented in Fig. 1 (a, b, c).

According to the results of dividing the output sequences into intervals and further calculation of their CCF, new ensembles of complex signal sequences with a low level of cross-correlation were obtained. An example of such a signal with the number of symbols $n=173$ is shown in Fig. 2. 


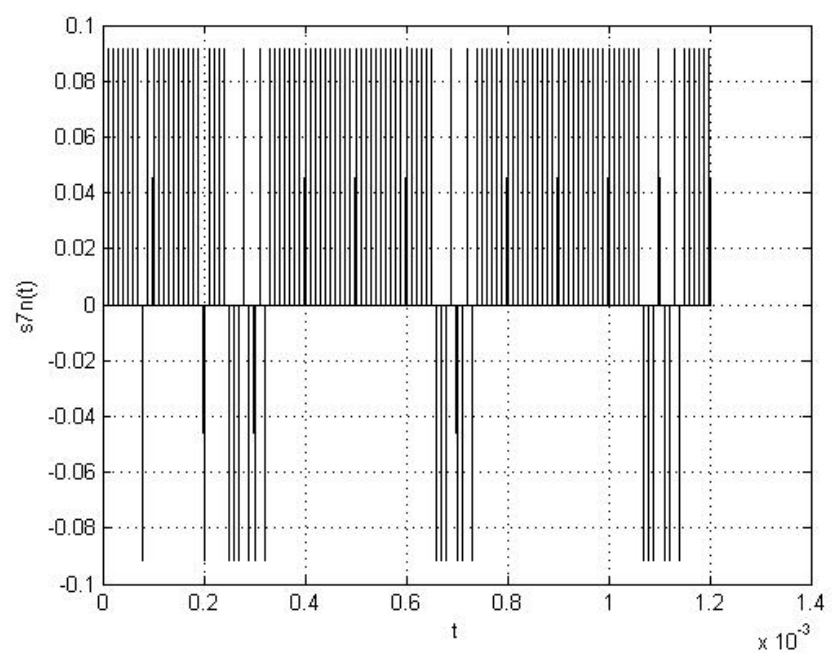

a
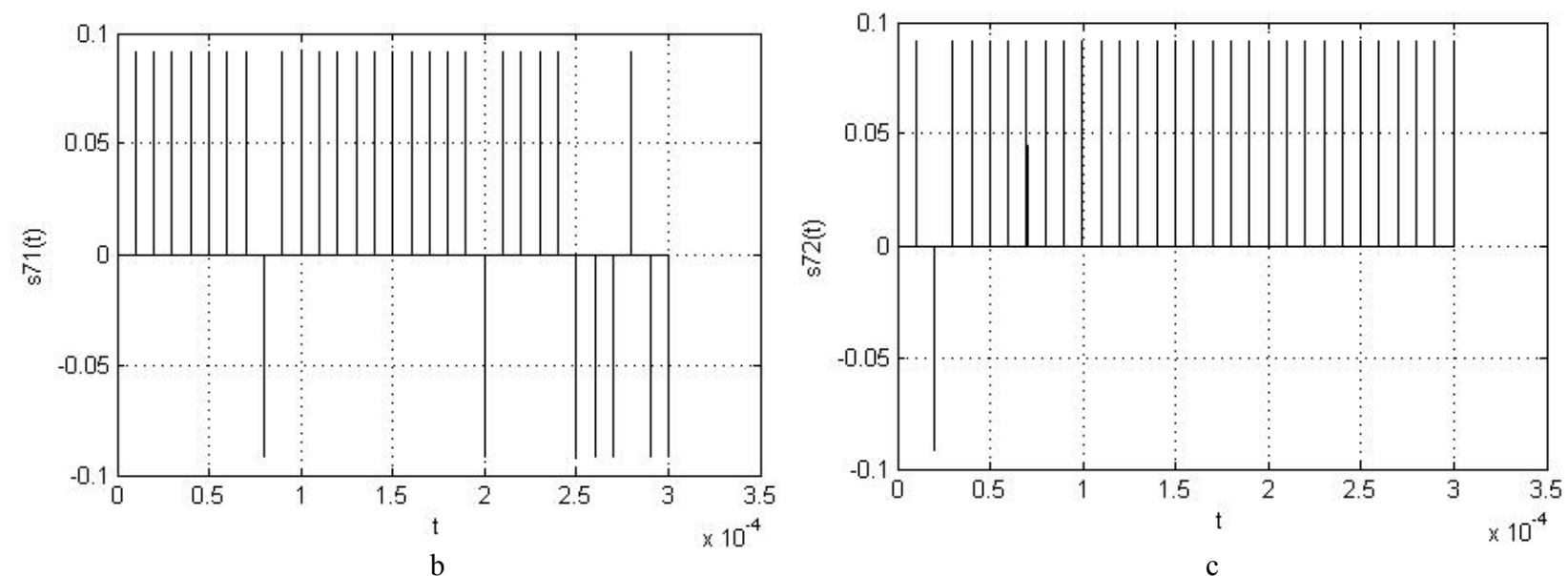

Fig. 1: $\mathrm{a}$ - an example of the output sequence;

$\mathrm{b}$ - an example of the first interval of the sequence division; $\mathrm{c}$ - an example of the second interval of the sequence division

Fig. 2 shows that as a result of the time interval allows forming on their basis complex signal permutations, the sequences with minimal interaction ensembles with a larger volume, relative to the in time and low correlation were received, which original sequences.

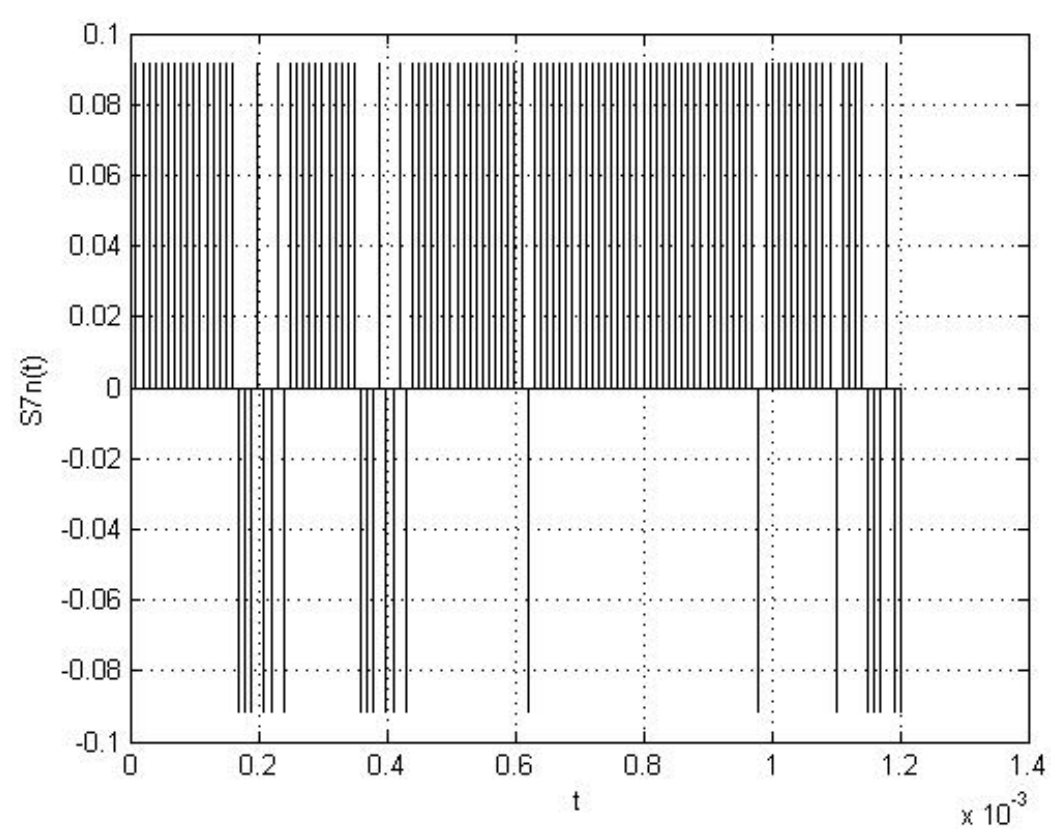

Fig. 2. An example of complex signal sequence from the resulting ensemble with a low level of cross-correlation 
To calculate the maximum emissions values of the side lobes of the $\mathrm{CCF}$, obtained as a result of the sequences permutations, use the expression [7]:

$$
R_{i j}=1 / \sqrt{n_{i} n_{j}} \text {. }
$$

Due to the different number of pulses in the sequences, the signal energies will be different.
Therefore, for assessment of the CCF by expression (3) it is necessary to normalize the signals energy values [1]:

$$
S_{\text {ihopm }}(t)=S_{i}(t) / \sqrt{E_{i}} .
$$

The calculated maximum values of the $\mathrm{CCF}$ sequences are shown in Table 1.

Table 1 - The result of calculating the maximum values of the CCF

\begin{tabular}{|l|l|l|l|l|l|l|l|l|l|l|}
\hline & $\operatorname{maxR1}$ & $\operatorname{maxR2}$ & $\operatorname{maxR3}$ & $\operatorname{maxR4}$ & $\operatorname{maxR5}$ & $\operatorname{maxR6}$ & $\operatorname{maxR7}$ & $\operatorname{maxR8}$ & $\operatorname{maxR9}$ & $\operatorname{maxR10}$ \\
\hline $\operatorname{maxR1}$ & 1 & 0,0204 & 0,0097 & 0,0093 & 0,0095 & 0,0093 & 0,0093 & 0,0093 & 0,0093 & 0,0093 \\
\hline $\operatorname{maxR2}$ & 0,0204 & 1 & 0,0095 & 0,0091 & 0,0091 & 0,0093 & 0,0091 & 0,0091 & 0,0091 & 0,0091 \\
\hline $\operatorname{maxR3}$ & 0,0097 & 0,0095 & 1 & 0,0087 & 0,0089 & 0,0087 & 0,0087 & 0,0087 & 0,0087 & 0,0087 \\
\hline $\operatorname{maxR4}$ & 0,0093 & 0,0091 & 0,0087 & 1 & 0,0085 & 0,6917 & 0,525 & 0,8 & 0,8 & 0,75 \\
\hline $\operatorname{maxR5}$ & 0,0095 & 0,0091 & 0,0089 & 0,0085 & 1 & 0,0085 & 0,0085 & 0,0085 & 0,0085 & 0,0085 \\
\hline $\operatorname{maxR6}$ & 0,0093 & 0,0093 & 0,0087 & 0,6917 & 0,0085 & 1 & 0,7167 & 0,5833 & 0,5333 & 0,5333 \\
\hline $\operatorname{maxR7}$ & 0,0093 & 0,0091 & 0,0087 & 0,525 & 0,0085 & 0,7167 & 1 & 0,5250 & 0,4833 & 0,5350 \\
\hline $\operatorname{maxR8}$ & 0,0093 & 0,0091 & 0,0087 & 0,8 & 0,0085 & 0,5833 & 0,5250 & 1 & 0,8 & 0,75 \\
\hline maxR9 & 0,0093 & 0,0091 & 0,0087 & 0,8 & 0,0085 & 0,5333 & 0,4833 & 0,8 & 1 & 0,95 \\
\hline maxR10 & 0,0093 & 0,0091 & 0,0087 & 0,75 & 0,0085 & 0,5333 & 0,5350 & 0,75 & 0,95 & 1 \\
\hline
\end{tabular}

Fig. 3 shows the visualization of the CCF of the side lobes of the CCF for the obtained sequences calculation result and the points of maximum emissions with minimal energy interaction.

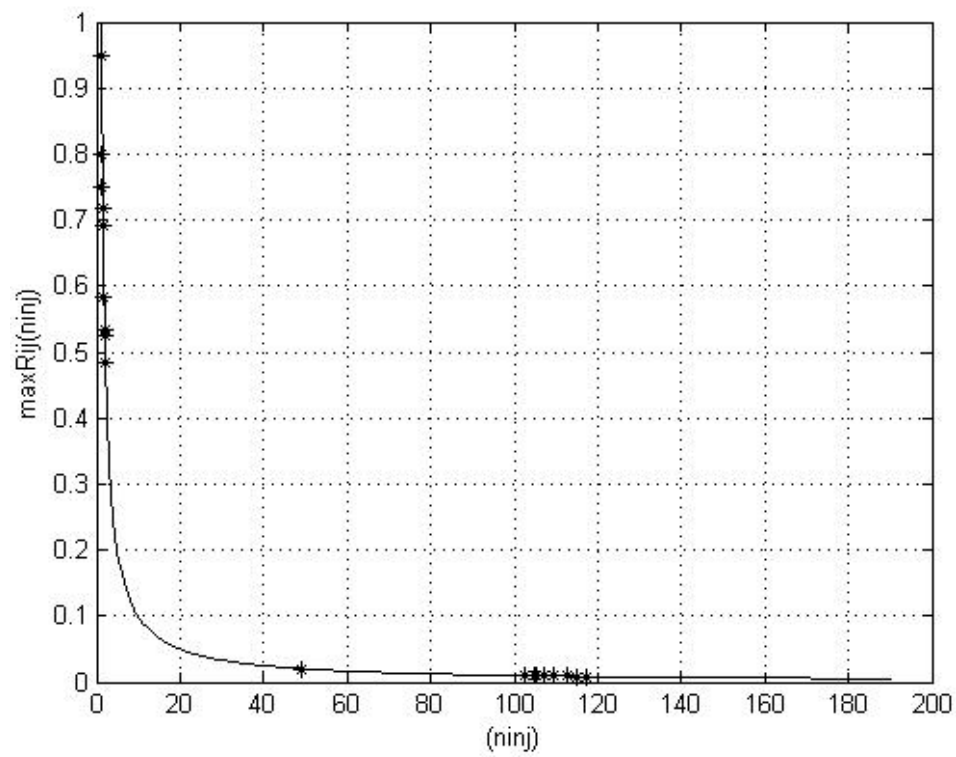

Fig. 3. The result of calculating the CCF maxima and the points of maximum emissions of the side lobes of the $\mathrm{CCF}$

Table 1 and Fig. 3 show that the calculated values of the CCF maxima with the minimum energy interaction of the new sequences are compared with the maximum emissions values of the side lobes of the signals CCF involved in the permutations. As a result, we see that the obtained sequences provide the condition of minimal similarity (1).

\section{Conclusion}

Application of time permutations on the basis of a rating series with the arrangement of values according to the chosen general average value for the volume increase in complex signals ensembles allow receiving complex signals sequences with quite a low level of cross-correlation, thus the interaction between signals in time domain remains at a low level, which has a positive effect on the level of multiple access interference.

At the same time, the cross-correlation properties will be slightly worsened, as the maximum emissions values of the side lobes of the CCF signals depend on the number of splitting intervals, but, nevertheless, it becomes possible to use them in modern multiple access radio systems. 
REFERENCES

1. Ipatov, V.P. (2007), Spread Spectrum and CDMA. Principles and Applications, Technosphera, Moscow, 488 p., ISBN 978-594836-128-4.

2. Semenikhin, V.S. and Pishkin, I.M. (1990), Land mobile radio, Radio and communications, Moscow, $432 \mathrm{p}$.

3. Borisov, V.I. (2003), Interference Protection of radio communication systems, Radio and communications, Moscow, 640 p.

4. Bernard, Sklar (2003), Communications: Fundamentals and Applications, Publishing house "Williams", Moscow, 1104 p.

5. Maksimov, M.V. (1999), Protection from radio interference, Soviet radio, Moscow, 496 p.

6. Varakin, L.E. (1985), Communication systems with noise-like signals, Radio and communication, Moscow, 384 p.

7. Stepanenko, Y.G. and Lysechko, V.P. (2009), "Method for determining the period of short video pulses in code sequences based on the Heaviside function approximation", Weapons systems and military equipment, Vol. 4(20), pp. 170-173.

Received (Надійшла) 10.07.2020

Accepted for publication (Прийнята до друку) 23.09.2020

\section{ВідОмості ПРо АВТоРів / AвоUт тHE AUTHORS}

Лисечко Володимир Петрович - кандидат технічних наук, доцент, доцент кафедри транспортного зв’язку, Український державний університет залізничного транспорту, Харків, Україна;

Volodymyr Lysechko - PhD (Technical), Associate Professor, Associate Professor of Transport Communications Department, Ukrainian State University of Railway Transport, Kharkiv, Ukraine; e-mail: lysechkov@ukr.net; ORCID ID: http://orcid.org/0000-0002-1520-9515.

Індик Сергій Володимирович - старший викладач кафедри транспортного зв'язку, Український державний університет залізничного транспорту, Харків, Україна;

Serhii Indyk - Senior Lecturer of Transport Communications Department, Ukrainian State University of Railway Transport, Kharkiv, Ukraine;

e-mail: sergiy.indyk@,gmail.com; ORCID ID: http://orcid.org/0000-0003-3124-8722.

\section{Дослідження властивостей ансамблів складних сигналів, отриманих шляхом перестановок часових інтервалів}

С. В. Індик, В. П. Лисечко

Анотація. У статті наведено результати статистичного аналізу взаємокореляційних властивостей ансамблів складних сигналів, які були отримані за рахунок перестановок часових інтервалів. Суть методу полягає у застосуванні розбиття послідовностей коротких відеоімпульсів на рівні інтервали з низькою взаємодією у часовій області з різною кількістю імпульсів. Шляхом застосування взаємокореляційного аналізу здійснюють розрахунок значень максимальних викидів бічних пелюсток функцій взаємної кореляції та визначають їх загальне середнє значення. На основі отриманих значень складають ряд, в якому першу позицію займає часовий інтервал, у якому величина максимальних викидів бокових пелюсток функції взаємної кореляції має середнє значення. Визначення наступних часових інтервалів відбувається на основі аналізу рейтингового ряду і розстановка значень проводиться у відповідності до обраного загального середнього значення. Таким чином формують новий усереднений ряд значень максимальних викидів бокових пелюсток функції взаємної кореляції, завдяки якому збільшується кількість ансамблів із задовільними взаємокореляційними властивостями для використання в системах радіозв'язку з кодовим розділенням каналів, а мінімальна взаємодія між сигналами у часовій області призводить до зменшення завад множинного доступу.

Кл ючов і слов а : завада множинного доступу; відео імпульс; база сигналу; ширина спектру сигналу; тривалість сигналу; ширина спектру сигналу; пік - фактор; шпаруватість; тривалість імпульсу; функція взаємної кореляції.

\section{Исследование свойств ансамблей сложных сигналов, полученных путем перестановок временных интервалов}

\section{С. В. Индык, В. П. Лысечко}

Аннотация. В статье приведены результаты статистического анализа взаимокорреляционных свойств ансамблей сложных сигналов, полученных за счет перестановок временных интервалов. Суть метода заключается в применении разбиения последовательностей коротких видеоимпульсов на равные промежутки с низким взаимодействием во временной области с разным количеством импульсов. Путем применения взаимокорреляционного анализа осуществляют расчет значений максимальных выбросов боковых лепестков функции взаимной корреляции и определяют их общее среднее значение. На основе полученных значений составляют ряд, в котором первую позицию занимает временной интервал, величина максимальных выбросов боковых лепестков функции взаимной корреляции которого имеет среднее значение. Определение следующих временных интервалов происходит на основе анализа рейтингового ряда, и расстановка значений проводится в соответствии с выбранным общим средним значением. Таким образом формируют новый усредненный ряд значений максимальных выбросов боковых лепестков функции взаимной корреляции, благодаря которому увеличивается количество ансамблей с удовлетворительными взаимокорреляционными свойствами для использования в системах радиосвязи с кодовым разделением каналов, а минимальное взаимодействие между сигналами во временной области приводит к уменьшению помех множественного доступа.

Ключевые слова: помеха множественного доступа; видеоимпульс; база сигнала; ширина спектра сигнала; длительность сигнала; пик - фактор; скважность; длительность импульса; функция взаимной корреляции. 